\title{
VODA V PRSTI IN UGOTAVLJANJE NJENEGA RAZPOREJANJA V ODVISNOSTI OD RELIEFA
}

\author{
Blaž Repe \\ Oddelek za geografijo Filozofska fakulteta Univerza v Ljubljani, Aškerčeva 2 \\ SI-I000 Ljubljana, Slovenija \\ e-mail: blazrepe@yahoo.com
}

Izvirni znanstveni članek

COBISS 1.01

\begin{abstract}
Izvleček
Podatki o količini vode v prsteh Slovenije so skromni in še to so najpogosteje na voljo le v točkovni obliki, kar je težko posplošiti na večje območje. Zato smo razporeditev skušali oceniti na podlagi reliefnih podatkov. Kot merilo razporeditve vode v prsti v pokrajini smo uporabili reliefni indeks vlažnosti. Reliefni indeks vlažnosti kaže na stopnjo akumulacije vode $\mathrm{v}$ prsti na določeni izbrani lokaciji, ki je funkcija naklona na tej lokaciji in specifične površine porečja gorvodno od te točke.
\end{abstract}

Ključne besede: fizična geografija, pedogeografija, pedogenetski dejavniki, voda v prsti, reliefni indeks vlažnosti, GIS.

\section{SOIL WATER CONTENT AND ITS DISTRIBUTION ACCORDING TO RELIEF}

\begin{abstract}
There is very little soil water data in Slovenia. Most of them point oriented and is therefore very difficult to generalize on larger areas. The distribution of soil water was estimated using relief data. For quantitative measure of soil water topographical wetness index (TWI) had been used. Topographical wetness index shows water accumulation in a given location and is a function of slope and upslope specific catchment area.
\end{abstract}

Key words: physical geography, soil geography, factors of soil formation, soil water, topographical wetness index, GIS. 


\section{UVOD}

Vse, kar vpliva na nastanek, razvoj in lastnosti prsti ter istočasno na njihovo razširjenost, lahko strnemo pod pojmom pedogenetski (tlotvorni) dejavniki. Z vidika sistemske teorije so to dejavniki okolja oziroma geografskega okolja, pokrajine, ki delujejo na proučevani podsistem, to je na prst (Lovrenčak, 1994).

Do takšnih zaključkov se je dokopal že Dokučajev, temelje pa postavi Jenny leta 1941, ko je vpliv pedogenetskih faktorjev na nastanek in razvoj prsti zapisal v obliki matematične formule:

$$
\mathrm{S}=\mathrm{f}(\mathrm{cl}, \mathrm{o}, \mathrm{r}, \mathrm{p}, \mathrm{t})
$$

kjer je prst (Soil) funkcija (function) pedogenetskih dejavnikov: podnebja (climate) živega sveta (organisms), reliefa (relief), matične podlage (parent material) in časa (time).

Za slovenske razmere pa tako nabor kakor tudi razporeditev dejavnikov ni ustrezna oziroma je premalo podrobna. Stritar je formulo priredil za slovenske razmere in jo poznamo kot Stritarjevo formulo (Prus, 2000):

$$
\mathrm{T}=\mathrm{f}(\mathrm{G}, \mathrm{V}, \mathrm{R}, \mathrm{K}, \mathrm{O}, \check{\mathrm{C}}) \mathrm{t}(\text { Stritar, 1991) }
$$

Razvoj in lastnosti tal/prsti so odvisne od geolitološke osnove (matične podlage), reliefa, klime, vodnih razmer, organizmov, človeka in časa (t).

Slika 1: Pedogenetski dejavniki

Figure 1: Factors of soil formation

avtor in oblikovanje:

Blaž Repe

Oddelek za geografijo,

Filozofska fakulteta

Ljubljana 2006

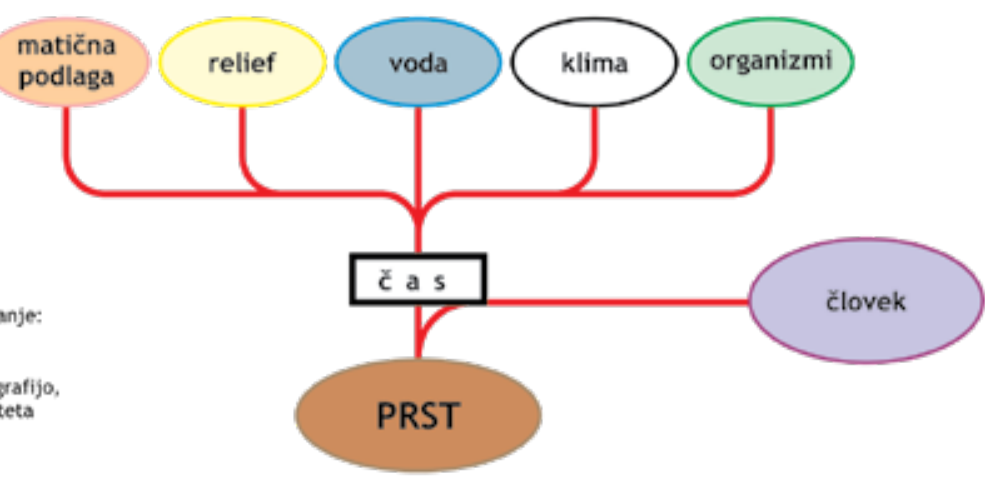

Vsaka prst, njene lastnosti in procesi, ki potekajo v njej, so rezultat vzajemnega delovanja vseh teh dejavnikov. Čeprav pogosto lokalno en dejavnik prevlada nad ostalimi in je vpliv nekaterih komaj čutiti (Repe, 2006). Pomembnost oziroma odločilnost posameznih pedogenetskih dejavnikov je odvisna od merila, v katerem proučujemo prsti.

Voda predstavlja izjemno pomemben pedogenetski faktor, ki ima v slovenski klasifikaciji prsti še posebno težo, saj na prvem nivoju poteka delitev prsti na avtomorfne in 
hidromorfne (tudi na subakvalne in halomorfne) prav na podlagi vpliva vode (Repe, 2004). Kljub vsemu pa se voda kot pedogenetski dejavnik ter njena vsebnost v prsteh pogosto ne obravnava samostojno, ampak v sklopu drugih dejavnikov, še posebej reliefa in podnebja. Če je tak pristop na globalnem nivoju ustrezen, pa moramo v regionalnem merilu vodo vsekakor posebej izločiti (Prus, 2000).

Premikanje vode v prsti povzročajo sile. Kristalna, kemično vezana voda miruje, vodni hlapi in higroskopska voda migrirata na podlagi termodinamičnih zakonov, kapilarno vodo adsorpcijske sile vlečejo v vse smeri, gravitacijska voda teži k zmanjšanju potencialne energije in se zato premika $v$ glavnem navzdol v relativno nižje dele profila in absolutno v nižje ležeče dele pokrajine. Ob dokaj enotnih klimatskih pogojih, je za razlago razporeditve vode v prsteh, treba poleg splošnih hidroloških poznati predvsem reliefne razmere. Relief namreč v dobršni meri odloča, kako in kam se bosta premikali padavinska voda po površju in gravitacijska voda $\mathrm{v}$ prsti oziroma, kje se bodo razvile avtomorfne ali hidromorfne razmere.

Preglednica 1: Vpliv vode na nastanek in razvoj prsti

Table 1: Influence of water on soil development

\begin{tabular}{|l|l|l|l|}
\hline & smer vpliva & vrsta vpliva & posledica vpliva \\
\hline $\begin{array}{l}\text { padavinska } \\
\text { voda }\end{array}$ & $\begin{array}{l}\text { gibanje pretežno } \\
\text { navzdol }\end{array}$ & premeščanje snovi navzdol & $\begin{array}{l}\text { nastanek novih horizontov, } \\
\text { spremembe vsebnosti bazičnih } \\
\text { kationov, gline, organske snovi, } \\
\text { oksidov in hidroksidov, konkrecije } \\
\text { karbonatov, psevdomicelij }\end{array}$ \\
\hline $\begin{array}{l}\text { ascendenčna } \\
\text { voda }\end{array}$ & $\begin{array}{l}\text { vzpenjanje } \\
\text { iz podtalnice } \\
\text { (kapilarni vzpon) }\end{array}$ & $\begin{array}{l}\text { premeščanje raztopljenih } \\
\text { snovi navzgor }\end{array}$ & $\begin{array}{l}\text { obloge na površju prsti, pretežno } \\
\text { soli varidnih območjih, povečan } \\
\text { delež natrijevih kationov v } \\
\text { površinskem delu prsti }\end{array}$ \\
\hline $\begin{array}{l}\text { površinski } \\
\text { odtok }\end{array}$ & $\begin{array}{l}\text { odtok po padnici } \\
\text { terena }\end{array}$ & $\begin{array}{l}\text { površinsko premeščanje } \\
\text { delcev prsti pa tudi večjih } \\
\text { talnih gmot vključno s } \\
\text { kamninskim materialom }\end{array}$ & $\begin{array}{l}\text { soliflukcija, erozija in koluviacija } \\
\text { (deluvijacija), plazenje, usadi in } \\
\text { udori, pogrebeni horizonti }\end{array}$ \\
\hline $\begin{array}{l}\text { zastajanje } \\
\text { vode }\end{array}$ & $\begin{array}{l}\text { občasno ali } \\
\text { dolgotrajnejše } \\
\text { lateralno } \\
\text { zastajanje v } \\
\text { različnih globinah } \\
\text { profila prsti }\end{array}$ & $\begin{array}{l}\text { oksidacijski in redukcijski } \\
\text { procesi, hidrogena } \\
\text { akumulacija organskih } \\
\text { snovi }\end{array}$ & $\begin{array}{l}\text { marmorirani oksidacijsko- } \\
\text { redukcijski horizonti, konkrecije } \\
\text { železa in mangana, šota }\end{array}$ \\
\hline
\end{tabular}

vir: Prus, 2000

\section{RELIEFNI INDEKS VLAŽNOSTI}

Ugotavljanje količine vode v prsti zahteva obilico terenskega dela (Metodika ..., 1967; Soil Survey Division Staff, 1993; SOTER, 1995; Vrščaj, 1996; Repe, 2001; Vovk Korže in Lovrenčak, 2001; Vrščaj s sod., 2001; Vovk Korže in Lovrenčak, 2004). Terenske ugotovitve ali kasnejše laboratorijske meritve prinesejo točkaste informacije o absolutni ali relativni 
količini vode v prsti, kar je dokaj težko realno posplošiti na celotno območje proučevanja. Vodne razmere so poleg tega zelo pogosto odraz vremenske situacije in letnega časa $\mathrm{v}$ času vzorčenja, to pa skoraj onemogoča primerjavo količin vode različnih tipov prsti ali istih tipov na različnih matičnih podlagah, tipih reliefa itd. Ker pogosto potrebujemo primerjalno informacijo o količini vode v prsteh za večje območje, bomo skušali njeno vsebnost oceniti na podlagi vodnih in reliefnih parametrov. Prikazali bomo izračun reliefnega indeksa vlažnosti in za primerjavo tudi gostoto rečne mreže ter njuno uporabnost pri napovedovanju in oceni količine vode $\mathrm{v}$ prsti.

Kot glavno osnovo za oceno količine in razporeditve vode v prsti smo uporabili reliefni indeks vlažnosti TWI (topographic wetness index - okrajšava oziroma oznaka reliefnega indeksa vlažnosti ostaja $\mathrm{v}$ originalnem, angleškem zapisu, ker gre za prepoznaven, uveljavljen in standarden zapis parametra in ne zgolj za kratico). (Kirkby, 1978; Moore s sod., 1993; Western s sod., 1999). Reliefni indeks vlažnosti kaže na stopnjo akumulacije vode v prsti na določeni izbrani lokaciji, ki je funkcija naklona na tej lokacijo in specifične površine porečja gorvodno od te točke (specific catchment area). Specifična površina porečja je merilo količine dotoka, naklon pa odtoka vode iz izbrane lokacije. Reliefni indeks vlažnosti (TWI) v določeni točki izračunamo kot naravni logaritem količnika med specifično površino porečja $(A s)$ in tangensom naklona $(\beta)$ pobočja $v$ isti točki:

$$
T W I=\ln \left(\begin{array}{cl}
A_{s} \\
\tan \beta
\end{array} \quad \begin{array}{l}
\text { As }- \text { specifična površina porečja }\left[\mathrm{m}^{2} / \mathrm{m}\right], \\
\beta-\text { naklon pobočja [radiani]. } \\
\text { ln - naravni logaritem }
\end{array}\right.
$$

Specifično površino (As) pa dobimo prav tako kot količnik med površino lokalnega porečja za izbrano točko (A) in dolžino enote plastnice (l) v isti točki:

$$
A s=\frac{A}{I} \quad \text { A - površina lokalnega porečja (glej akumulacijo vodnega toka) }\left[\mathrm{m}^{2}\right],
$$

Metodologija izračunavanja reliefnega indeksa vlažnosti in vrednosti, ki jih dobimo, je odvisna od načina izračuna specifične površine porečja; torej kako je opredeljen tok vode po pobočju navzdol oziroma na kakšen način se razporeja voda iz izbrane v sosednje celice. Obstaja več postopkov izračuna, $v$ osnovi pa jih smemo razdeliti v dve skupini:

- Algoritmi enosmernega toka, kjer se vodni tok usmerja $v$ eno, najnižje ležečo sosednjo celico od osmih možnih diskretnih smeri. Mednje uvrščamo najpogosteje uporabljen D8 algoritem (O'Callaghan in Mark, 1984).

- Algoritmi večsmernega toka, kjer je vodni tok mogoče zvezno usmeriti v katerokoli smer, obenem se tok proporcionalno razporedi med vse nižje ležeče sosednje celice. Mednje uvrščamo izboljšani D8 algoritem FD8 (Quinn s sod., 1995) in tudi D-infinity (slika 2), ki smo ga uporabili pri naših izračunih (D-inf ali D $\infty$ ) algoritem (Tarboton, 1997). 
Slika 2: Princip delovanja večsmernega Dœ algoritma (Tarboton, 1997)

Figure 2: The Do multiflow direction approach

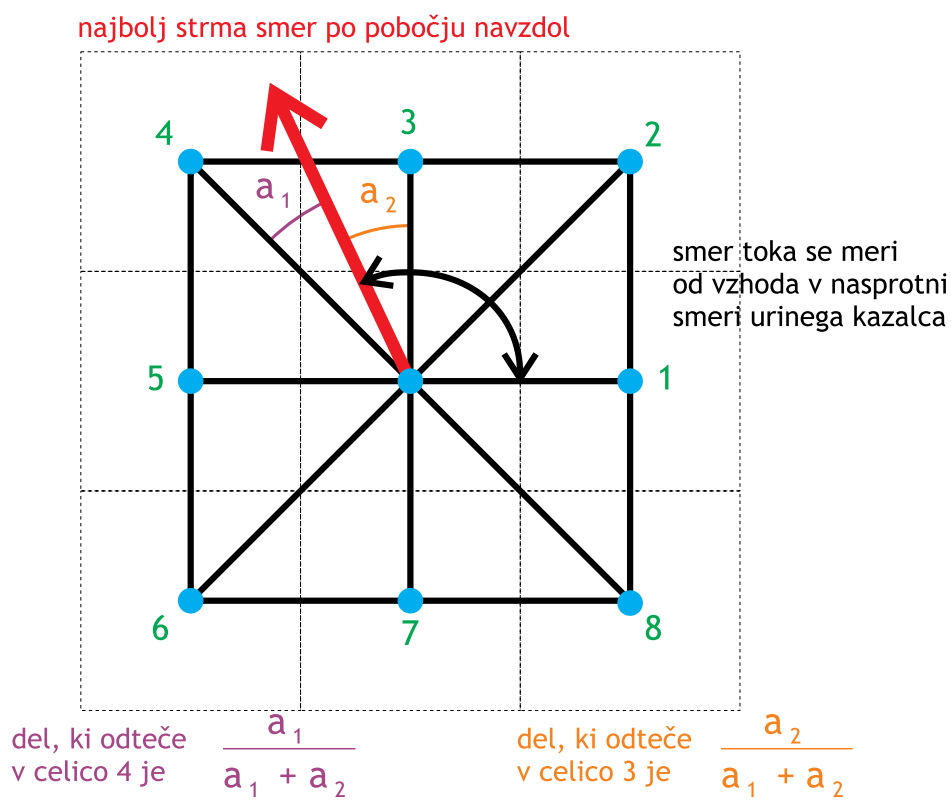

Izračuna reliefnega indeksa vlažnosti poteka na podlagi digitalnega modela nadmorskih višin. Izračun bo prikazan na digitalnemu modelu nadmorskih višin 100x100 m za celotno Slovenijo in 25x25 m za manjše proučevano območje (DMNV100, DMNV25; GURS, 2005). Kasnejša uporaba in vrednotenje indeksa bosta potekala za manjše območje. Postopek sestavlja več korakov:

1. Zapolnitev "lukenj" (fill pits). Iz osnovnega modela nadmorskih višin odstranimo luknje. Gre za ustaljen postopek pri rastrskih analizah vodnih tokov znotraj GIS, ko zapolnimo celice nižje od vseh ostalih okoliških osmih celic. Takšne celice predstavljajo lokalne ponore vodnega toka (na nepropustni podlagi bi morala tam nastati jezera). "Luknje" se v glavnem oblikujejo kot posledica interpolacijskih postopkov pri izdelavi digitalnega modela nadmorskih višin. Na takšnih lokalnih ponorih se algoritem računanja vodnega toka ustavi, zato jih je treba zapolniti (previšati).

2. Izračun površja smeri vodnega toka. Za izračun površja smo namesto enosmernega (npr. D-8) uporabili realnejšega, večsmernega D- $\infty$ algoritem (Tarboton, 2005).

3. Izračun površja akumulacije vodnega toka. Gre izračun števila celic, ki prispevajo vodni tok gorvodno od izbrane lokacije. Osnovni algoritem je prispeval Mark (1988) in je temeljil na D8 enosmernem toku. Vsaka celica dobi vrednost, ki je enaka seštevku svojega lastnega toka in toka vseh gorvodnih celic, ki steče vanjo. V našem primeru smo uporabili izboljšani D- $\infty$ večsmerni algoritem. 
Slika 3: Reliefni indeks vlažnosti TWI

Figure 3: Topographical wetness index TWI

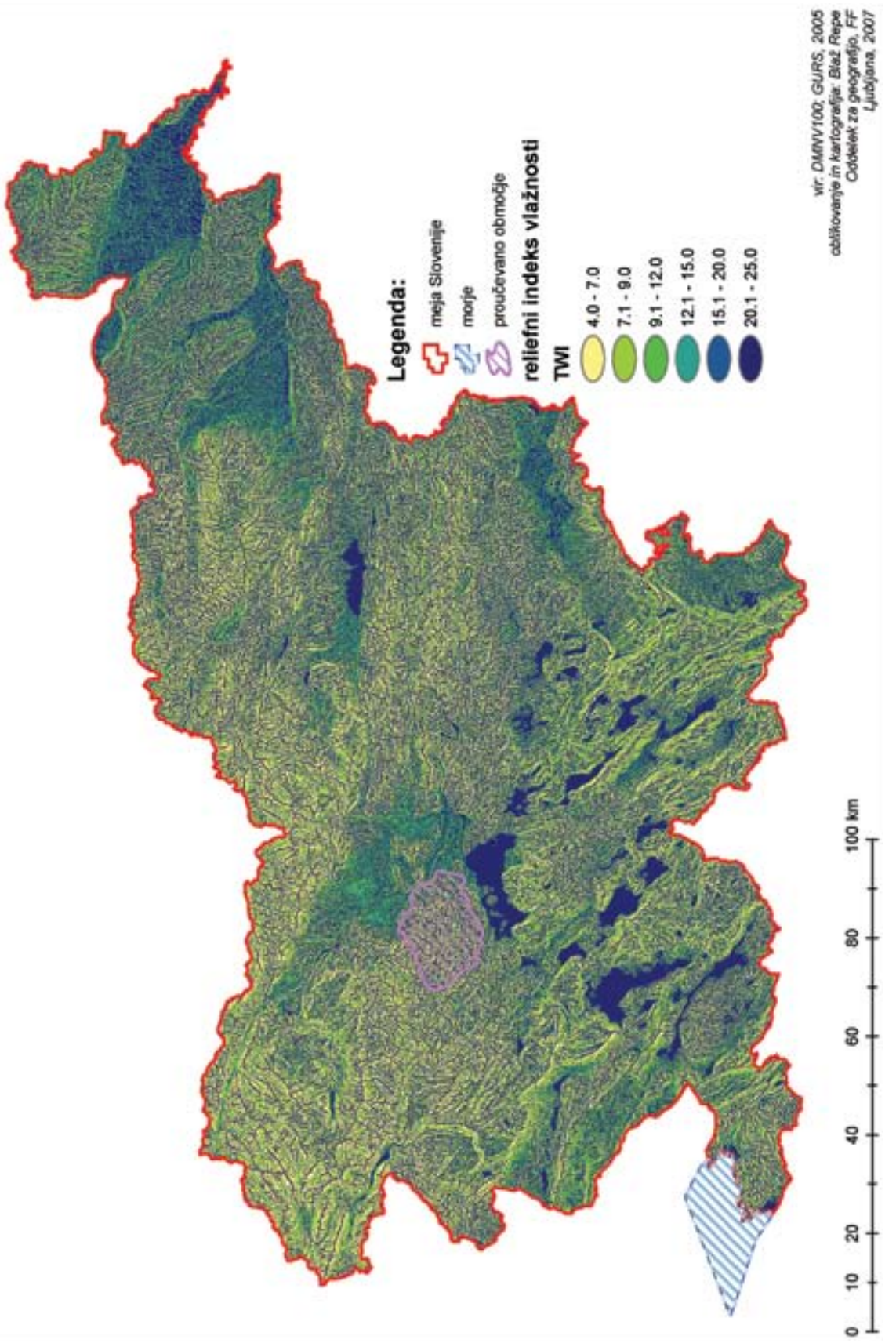


4. Izračun površine lokalnega porečja za vsako izbrano točko. Površino lokalnega porečja dobimo kot produkt akumulacije vodnega toka in površino ene celice. V našem primeru je celica velika 100x100 m, kar pomeni množenje s $10.000 \mathrm{~m}^{2}$.

5. Izračun površja specifične površine porečja. Specifično površino porečja končno dobimo z deljenjem lokalnega porečja z enoto platnice s, ki je v našem primeru 100 (kot je velikost celice).

6. Površje naklonov, ki smo ga prvotno izračunali v stopinjah, spremenimo v radiane in izračunamo njihov tangens.

7. Končni reliefni indeks vlažnosti (TWI) dobimo z logaritmiranjem količnika med specifično površino porečja in tangensom naklona pobočij (slika 3 ).

Tipične vrednosti reliefnega indeksa vlažnosti imajo razpon od 2 do 30 . Nižje vrednosti (pod 10) pomenijo zgornje, bolj strme dele pobočij in porečij od koder voda odteka. Tu pričakujemo sušnejše razmere v prsti, odnašanje prstenega materiala in posledično plitvejšo odejo prsti. Večje vrednosti reliefnega indeksa vlažnosti (nad 20) predstavljajo spodnje dele pobočij ali porečij, kjer se voda steka. Gre za ravninska ali uravnana območja, blizu lokalne erozijske baze in vodotokov. Značilni so nizki strmci, zastajanje vode in akumulacija prstene mase, zato so prsti debelejše in pogosto se pogosto razvijejo hidromorfne razmere (oglejevanje in psevdooglejevanje). Prednost indeksa TWI pred ostalimi kvantitativnimi opredelitvami površja, s katerimi je prav tako mogoče oceniti razporejanje vode v pokrajini je, da hkrati upošteva naklon pobočja, kumulativni vodni tok in obliko površja. Če podrobno pogledamo vrednosti reliefnega indeksa vlažnosti, opazimo, da se višje in visoke vrednosti pojavljajo tudi v grapah, na uravnavah in konkavnih delih sredi pobočji ter tudi ponekod na grebenih, kjer so nakloni blažji.

\section{PROUČEVANO OBMOČJE}

Reliefni indeks vlažnosti sicer predvideva teoretični vodni tok po površini, kjer pa teče le ob odsotnosti gozdne vegetacije in izjemno močnih padavinah. Ob normalnem deževju in prisotnosti gozda se večina padavinske voda infiltrira v profil prsti (del zadrži potem vegetacija), kjer sicer pronica počasneje, a še vedno v glavnem v isti smeri, kot bi tekla po površju. Zato smemo predpostaviti, da je količina vode, ki gravitacijsko teče skozi samo prst, odraz (sorazmerna) teoretičnega površinskega toka. Indeks pa seveda ne upošteva izgub vode med tokom, kot je evaporacija, transpiracija in pronicanje v notranjost propustne matične podlage ali dodatnega zadrževanja v profilu prsti zaradi težje teksture ali večjega deleža organske snovi itd. Zato je pravilna ocena relativne razporeditve vode v prsti z indeksom TWI $\mathrm{v}$ določeni pokrajini mogoča le takrat, ko imamo enotne geolitološke, podnebne, vegetacijske in pedološke razmere. V nasprotnem primeru se podoba razlikuje od teoretične in je potrebno poznavanje ostalih pedogenetskih dejavnikov in dodatna interpretacija razporejanja vode prsti.

Prsti, pedogenetske dejavnike in ostale vodne razmere smo proučevali v Polhograjskem hribovju (Slika 3). Meje proučevanega območja se dokaj dobro ujemajo z mejami Polhograjskega hribovja, kakor ga je opredelil Gabrovec (1989). Čeprav meje v glavnem potekajo po 
vodotokih ali na prehodu iz ravnine v pobočje, je naše proučevano območje malenkostno večje $\left(262,7 \mathrm{~km}^{2}\right)$. Tako smo zajeli tudi del zahodnega dna Ljubljanske kotline in zagotovili večjo pestrost pedogenetskih dejavnikov.

Za Polhograjsko hribovje je zelo značilna dvojnost med nekarbonatno in karbonatno matično podlago, ki se pogosto izmenjujeta na kratke razdalje $\mathrm{z}$ vmesnimi pasovi mladih kvartarnih sedimentov. Posledično se prepletata tudi normalen fluvialen relief in kraško površje z vsemi značilnimi pojavi (vrtače, ravniki, suhe doline, brezna itd.). Rečna mreža je gosta, kar kaže na sorazmerno dobro namočenost, čeprav imajo vodotoki nizke pretoke in so pogosto hudourniškega značaja. Polhograjsko hribovje je reliefno zelo razgibano, z zelo malo ravnega površja. Povprečna nadmorska višina znaša 540 metrov nad morjem, povprečen naklon je visok $\left(19^{\circ}\right)$. Podnebno je območje precej enotno, brez izrazitih temperaturnih, padavinskih ali drugih ekstremov. Polhograjsko hribovje pripada celinskemu tipu podnebja, ki je v Sloveniji najbolj razširjen. Povprečne količine padavin, ki so bile zabeležene, so med $1400 \mathrm{~mm}$ do največ $1800 \mathrm{~mm}$, povprečna letna temperatura meteoroloških postaj znotraj ali v neposredni bližini hribovja se giblje med $9,5^{\circ} \mathrm{C}$ in $7,5^{\circ} \mathrm{C}$. Povprečne januarske temperature so med $-0,5^{\circ} \mathrm{C}$ in $-2,0^{\circ} \mathrm{C}$, julijske pa med $17^{\circ} \mathrm{C}$ in $19^{\circ} \mathrm{C}$. Zaradi razgibanega reliefa je za doline Polhograjskega hribovja značilna temperaturna inverzija ter drobne klimatske razlike med prisojnimi in osojnimi pobočji. Pokrovnost (raba tal) površja je precej enotna, saj je delež gozda zelo visok (70 \%) in nad slovenskim povprečjem, obenem se je v zadnjih letih še povečal. Zaradi pestre geološke podlage so zelo pestre tudi gozdne združbe, čeprav izrazito prevladujejo bukovi gozdovi (Ogrin, 1996; Gams in Vrišer, 1998; Perko in Orožen Adamič, 1998; Repe, 2006).

Proučevano območje je v pretežni meri opredeljeno prav z rekami; Poljanska Sora na severu, Brebovščica na zahodu, na jugu je Horjulščica, le na vzhodu meja poteka po samem dnu Ljubljanske kotline. Gradaščica, kot osrednja reka Polhograjskega hribovja in proučevanega območja, zbira večino padavinske vode (vanjo se izliva tudi Horjulščica), le manjši vodotoki se izlivajo v Poljansko Soro, še manj pa neposredno iz Žlebskega gričevja v Savo. Rečna mreža je zaradi prevladujoče nepropustne matične podlage in dobre namočenosti precej gosta $\left(2,1 \mathrm{~km} / \mathrm{km}^{2} ;\right.$ Repe, 2006) in je precej nad slovenskim povprečjem $\left(1,5 \mathrm{~km} / \mathrm{km}^{2}\right.$; Radinja 1996).

Gradaščica je ne le osrednji, ampak tudi največji vodotok znotraj proučevanega območja in meri $14 \mathrm{~km}$, skupaj z Malo vodo pa $26 \mathrm{~km}$ v dolžino in odmaka $149,2 \mathrm{~km}^{2}$ veliko porečje z vsemi svojimi pritoki (Repe, 2006). Povprečni pretok ima $4,8 \mathrm{~m}^{3} / \mathrm{s}$ (Kolbezen, 1998). To pomeni, da $\mathrm{z}$ vsakega kvadratnega kilometra hribovitega zaledja vsako sekundo odteče 31 litrov $\left(33,6\right.$ l/s/ $\mathrm{km}^{2}$; Kolbezen, 1998) vode. Kar se tiče odtočnost padavin dobri dve tretjini odtečeta, slaba tretjina pa izhlapi, neposredno ali preko vegetacija (Radinja, 1996).

Posplošeno so pedološke razmere v Polhograjskem hribovju v glavnem odraz matične podlage, reliefa (naklona in nadmorske višine) in vodnih razmer. Na podlagi modeliranja pedogenetskih dejavnikov in obsežnega terenskega dela smo izdelali karto prsti, kjer se v deležih od celotne površine proučevanega območja pojavljajo naslednje enote (slika 4): obrečne prsti $(6 \%)$, koluvialne in psevdooglejene prsti $(5 \%)$, oglejene prsti $(1 \%)$, rankerji $(4 \%)$, distrične rjave prsti $(41 \%)$, rendzine $(30 \%)$, rjave pokarbonatne prsti $(11 \%)$ in izprane prsti (2\%) (Repe, 2006). 
Slika 4: Karta prsti proučevanega območja

Figure 4: Soil map of the research area

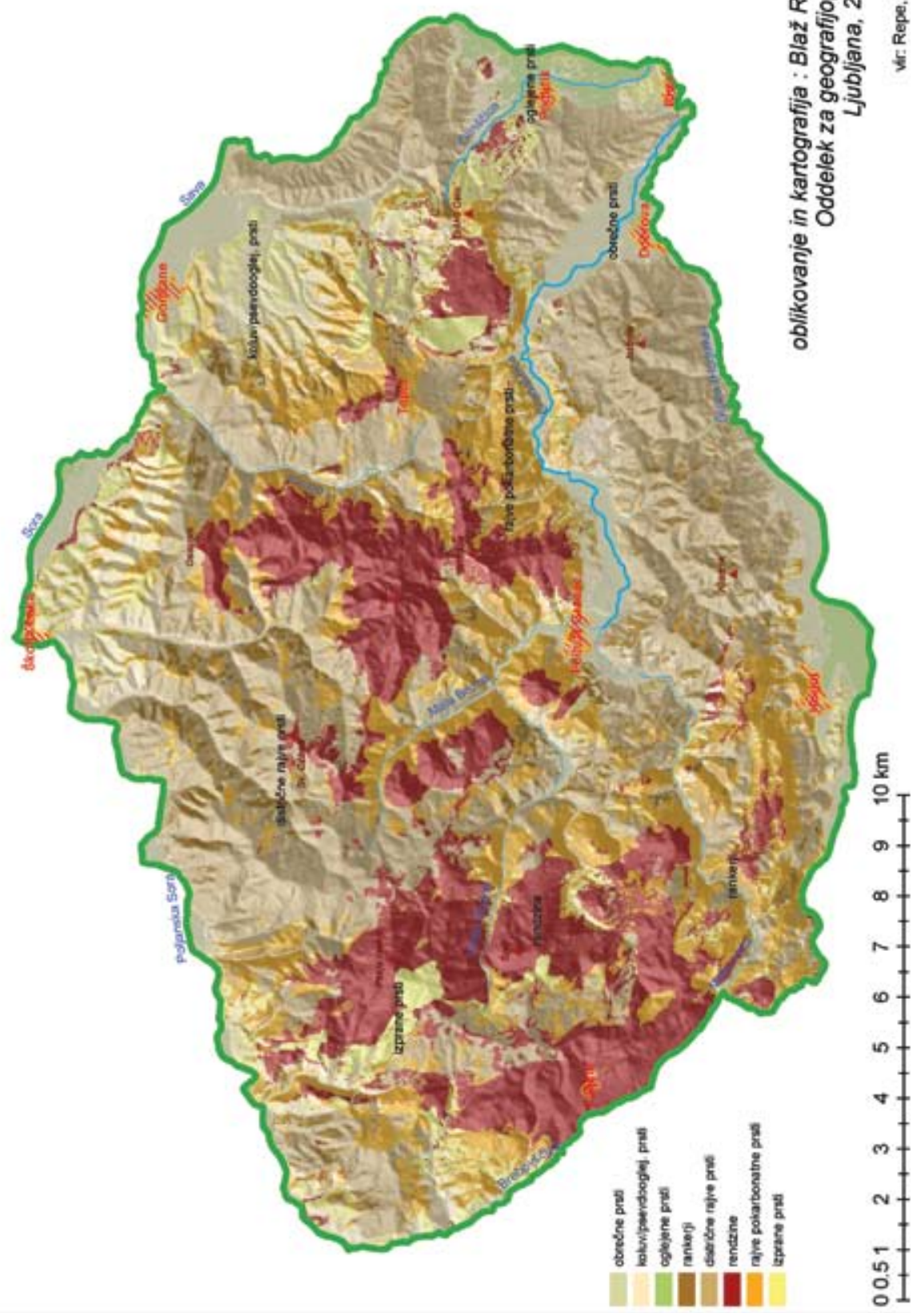


Slika 5: Reliefni indeks vlažnosti proučevanega območja

Figure 5: Topographical wetness index of the research area

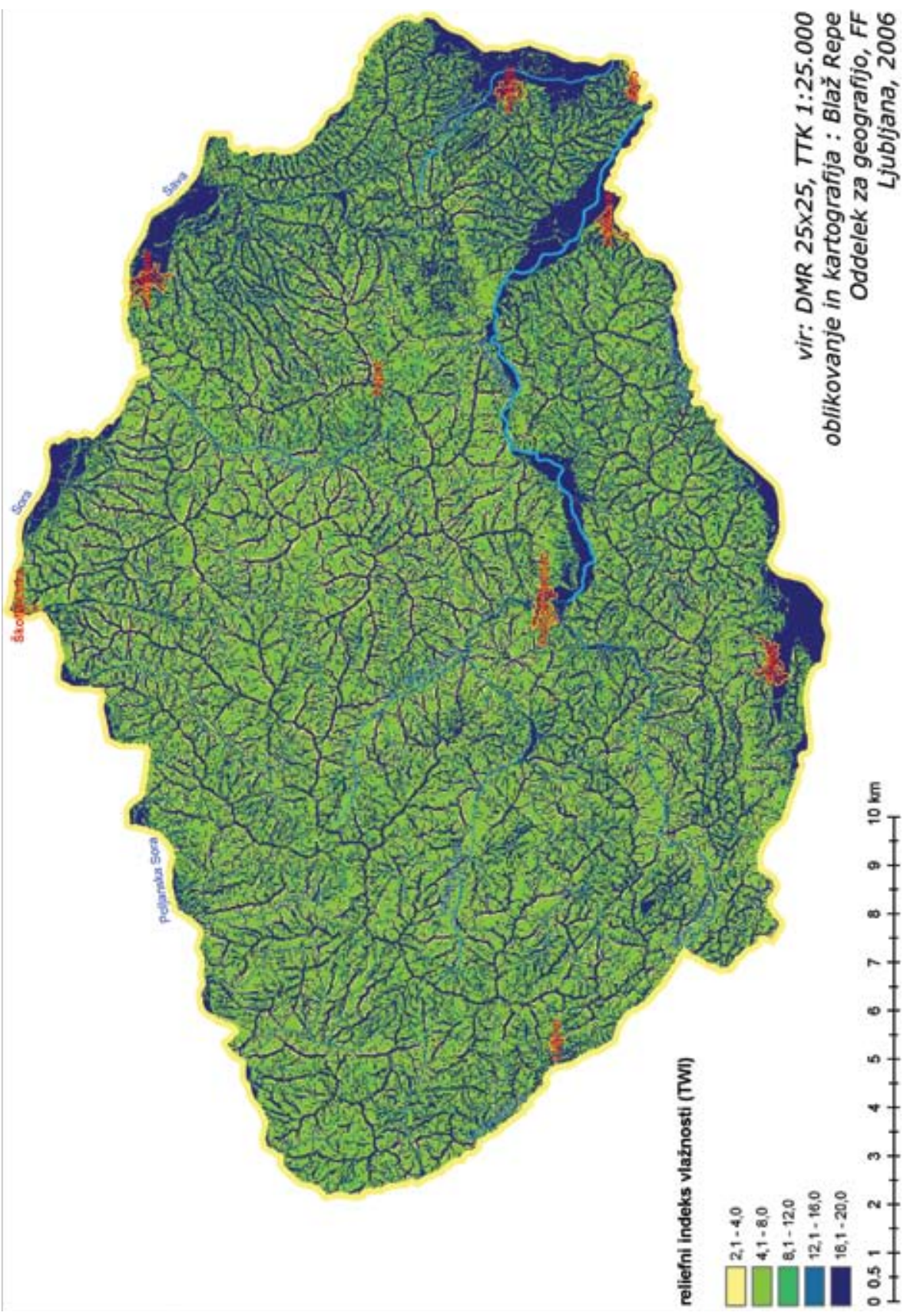




\section{RAZPOREDITEV VODE V PRSTEH PROUČEVANEGA OBMOČJA}

Kot merilo razporeditve vode v prsteh na proučevanem območju smo izračunali gostoto rečne mreže in reliefni indeks vlažnosti (Slika 5).

Z gostoto vodnih tokov moremo zadovoljivo opisati zelo splošne ugotovitve. Predvsem nas gostota opozarja na izrazito dvojnost matične podlage. Na eni strani permokarbonski nekarbonatni in nepropustni skrilavi glinavci, meljevci ter peščenjaki, kjer je razvita normalna rečna mreža $z$ nadpovprečnimi gostotami $\left(2-6 \mathrm{~km} / \mathrm{km}^{2}\right)$ in na drugi strani trdi, a propustni in zakraseli, v pretežni meri triasni apnenci in dolomiti, kjer je redka rečna mreža (gostota je v povprečju pod $1,5 \mathrm{~km} / \mathrm{km}^{2}$ ). Obenem pa nakazuje tudi na reliefno dvojnost, kjer je več kot manj kot 10\% uravnanega površja (ravninska dna) z ekstremnimi gostotami rečne mreže $\left(6-9 \mathrm{~km} / \mathrm{km}^{2}\right)$ in večino ostalega vzpetega površja, kjer so gostote nekako v povprečju. Na dejansko razporeditev vode, tudi tiste v prsti, kažejo vodne oziroma vzročno reliefne poteze in njihova že omenjena dvojnost. Odtočna količnika obeh najpomembnejših vodotokov Gradaščice in Horjulščice sta dokaj visoka (nad 60\%). To pomeni, da praktično vsa padavinska voda zaradi strmih pobočij odteče $\mathrm{v}$ dolino in se nato zbira $\mathrm{v}$ glavnih vodotokih. Strmca obeh rek sta ob vodomerni postaji majhna, voda odteka počasi in se zato pogosto zadržuje tudi v prsti. V dneh dolin smo tudi s terenskim proučevanjem potrdili in ugotovili pojavljanje hidromorfnih razmer.

Pri terenskem proučevanju smo ugotovili seveda precejšnje razlike v vsebnosti vode v prsti tudi znotraj območji, ki jih je mogoče izločiti in opisati z gostoto rečne mreže. Izrazite razlike se pojavljajo pri različnih oblikah distričnih rjavih prsti, še bolj pa je to izrazito pri rendzinah in rjavih pokarbonatnih prsteh. Razlike je moč zaznati med vrhom/grebenom, pobočjem ali vznožjem, pa tudi na pobočju samem, če gre za konkavno ali konveksno obliko. V veliko pomoč pri razlagi vodnih razmer v prsti se je izkazal prav reliefni indeks vlažnosti.

Razporeditev reliefnega indeksa vlažnosti kaže naslednje zakonitosti:

- Najnižje vrednosti (pod 5) se pojavljajo daleč od lokalnih in absolutne erozijske baze proučevanega območja. Obenem gre za relativno in absolutno najvišje dele vzpetih delov, kar predstavljajo predvsem vrhovi in grebeni, v našem primeru hribovja/gričevja.

- Hribovit značaj proučevanega območja botruje pojavljanju pretežno nizkih (od 5 do 10) in srednjih (od 10 do 15) vrednosti. V prve so zajeta so skoraj vsa nezakrivljena in konveksna pobočja, vsa močno nagnjena pobočja, skoraj ne glede na položaj (hiter površinski odtok) ter uravnave na višjih nadmorskih višinah; v slednja pa spodnji deli pobočij, relativno blizu dna grap.

- Visoke vrednosti (od 15 do 18) se nahajajo praviloma na konkavnih delih pobočij, kjer se voda zbira, nato na dnu grap, relativno precej oddaljenih od lokalne erozijske baze in na prehodu iz pobočja v ravnine, kjer se pojavlja vznožni koluvij.

- Najvišje vrednosti se (nad 18) nahajajo predvsem po celotnem dnu uravnanih, glavnih in največjih dolin, kamor se steka praktično vsa voda proučevanega območja povsod drugod in neposredno ob vodotokih, ne glede na velikost. 


\section{SKLEP}

Pričakovano imajo daleč največji reliefni indeks oglejene prsti, katerim sledijo obrečne prsti, saj je njihov najpomembnejši pedogenetski dejavnik voda (Preglednica 2). Višje vrednosti imajo tudi izprane prsti predvsem zaradi zadrževanja vode na bolj uravnanem reliefu, ki pogojuje njihov nastanek. Reliefni indeks vlažnosti tudi precej dobro razlikuje rankerje in distrične rjave prsti zaradi razloga, da se rankerji praviloma pojavljajo v zgornjih delih pobočij, na naklonih višjih od $25^{\circ}$ in so tudi vrednosti indeksa pod 10 . Razlike v naklonih površij, kjer se pojavljajo rendzine in rjave pokarbonatne prsti, so zelo neizrazite (Repe, 2006). Če razlika pri naklonih ni bila očitno v korist rendzin, pa to pride do izraza pri indeksu vlažnosti. Rendzine nastajajo tam, kjer je vpliv vode manjši, površja sušnejša, voda odteka hitreje, kar pa niso nujno tudi najvišji nakloni.

Preglednica 2: Opisne statistike reliefnega indeksa vlažnosti po skupinah prsti proučevanega območja

Table 2: Topographical wetness index descriptive statistics according to soil groups of the research area

\begin{tabular}{|l|c|c|c|c|c|}
\hline & \multicolumn{5}{|c|}{ reliefni indeks vlažnosti (TWI) } \\
\hline skupine prsti & min. & maks. & razpon & povp. & st.odkl. \\
\hline obrečne prsti & 4,90 & 20,00 & 15,10 & 16,84 & 5,39 \\
\hline koluv./psevdooglej. prsti & 3,01 & 20,00 & 16,99 & 9,53 & 6,02 \\
\hline oglejene prsti & 8,16 & 20,00 & 11,84 & 19,87 & 1,09 \\
\hline Rankerji & 2,90 & 20,00 & 17,10 & 8,33 & 6,06 \\
\hline distrične rjave prsti & 2,93 & 20,00 & 17,07 & 10,15 & 6,67 \\
\hline Rendzine & 2,87 & 20,00 & 17,13 & 9,32 & 6,87 \\
\hline rjave pokarbonatne prsti & 2,96 & 20,00 & 17,04 & 10,11 & 6,56 \\
\hline izprane prsti & 3,21 & 20,00 & 16,79 & 11,83 & 7,00 \\
\hline
\end{tabular}

Povsem podobne zaključke lahko izpeljemo tudi iz opisnih statistik gostote rečne mreže za posamezne tipe prsti, le da rendzine še bolj očitno izstopajo (Preglednica 3). Vendar pa izkušnje s terena kažejo, da gostota rečne mreže bolj kaže na ostale pedogenetske dejavnike (matična podlaga, relief, površinska rečna mreža), kot pa dejansko na razporeditev vode v prsti.

Na razporeditev vode v prsti smemo sklepati na podlagi različnih pedogenetskih dejavnikov in njihovih kvantitativnih parametrov, ki jih opredeljujejo.

Poleg precej splošnih sklepov, ki smo jih ugotovili na podlagi gostote rečne mreže, je reliefni indeks vlažnosti uporaben za natančnejše, mikro opredelitev vodnih razmer. V njegovo prid govori dejstvo, da indeks zajema hkrati več reliefnih in hidroloških parametrov in pravilno napoveduje teoretično razporeditev vode $v$ prsti. Reliefni indeks je še posebej dobrodošel na močno razgibanem površju, kjer je se nadmorska višina, naklon in oblika površja (ukrivljenost) spreminja na zelo kratke razdalje. $Z$ njim si lahko pomagamo tudi tam, kjer je rečna zaradi kraškega reliefa odsotna. 
Obenem pa se moramo zavedati, da je realna razporeditev vode odvisna predvsem od matične podlage in tipa prsti ter pokrovnosti (vegetacija), ki jih moramo za razlago nujno poznati in upoštevati. Velika pokritost Slovenije z gozdno vegetacijo tudi močno otežuje daljinsko zaznavanje (letalski, satelitski in radarski posnetki) absolutne količine vode v prsti, kar je v svetu zelo pogosto uporabljena metoda. Modeliranje različnih parametrov pa ne more nadomestiti, žal zamudnih in dolgotrajnih terenskih opazovanj in laboratorijskih analiz, ki pa omogočajo določanje absolutne in dejanske količine vode v prsti.

Preglednica 3: Opisne statistike gostote rečne mreže $\left(\mathrm{km} / \mathrm{km}^{2}\right)$ po skupinah prsti proučevanega območja

Table 3: River network density $\left(\mathrm{km} / \mathrm{km}^{2}\right)$ descriptive statistics according to soil groups of the research area

\begin{tabular}{|l|c|c|c|c|c|}
\hline & \multicolumn{5}{|c|}{ gostota rečne mreže } \\
\hline skupine prsti & min. & maks. & razpon & povp. & st.odk1. \\
\hline obrečne prsti & 0.32 & 9.74 & 9.43 & 3.58 & 1.29 \\
\hline koluv./psevdooglej. prsti & 0.00 & 9.43 & 9.43 & 2.95 & 1.20 \\
\hline oglejene prsti & 0.00 & 9.84 & 9.84 & 3.76 & 2.39 \\
\hline Rankerji & 0.00 & 7.64 & 7.64 & 2.80 & 1.18 \\
\hline distrične rjave prsti & 0.00 & 7.94 & 7.94 & 2.62 & 1.39 \\
\hline Rendzine & 0.00 & 5.48 & 5.48 & 1.48 & 1.01 \\
\hline rjave pokarbonatne prsti & 0.00 & 7.64 & 7.64 & 2.13 & 1.12 \\
\hline izprane prsti & 0.00 & 7.24 & 7.24 & 2.31 & 1.20 \\
\hline
\end{tabular}

\section{Viri in literatura}

Arhiv HMZ R Slovenije (sedaj Urad za meteorologijo Agencije RS za okolje). Klimatski podatki za slovenske meteorološke postaje za obdobje $1961-2000$.

Digitalni model nadmorskih višin 100x100m, 2005. Geodetska uprava republika Slovenije. Digitalni model nadmorskih višin 25x25m, 2005. Geodetska uprava republika Slovenije.

Gabrovec, M., 1989. Vloga reliefa za geografsko podobo Polhograjskega hribovja. Magistrsko delo. Oddelek za geografijo, Filozofska fakulteta, univerza v Ljubljani. Ljubljana. 84 str.

Gams, I., Vrišer, I. (ur.), 1998. Geografija Slovenije. Slovenska matica. Ljubljana. 501 str.

Hidrološki letopis Slovenije. Agencija republike Slovenije za okolje (Hidrometeorološki zavod Slovenije), Ministrstvo za okolje in prostor.

Jenny, H., 1941. Factors of Soil Formation. McGraw-Hill, New York.

Kirkby, M., 1978. Hillslope Hydrology. Wiley.

Klimatografija Slovenije, 1995. Temperatura zraka 1961 - 1990. HMZ R Slovenije. Ljubljana. $356 \mathrm{str}$.

Klimatografija Slovenije, 1995a. Padavine 1961 - 1990. HMZ R Slovenije. Ljubljana. 366 str. Kolbezen, M., 1998. Površinski vodotoki in vodna bilanca Slovenije. Ministrstvo za okolje in prostor: Hidrometeorološki zavod Republike Slovenije, Ljubljana. 98 str. 
Lovrenčak, F., 1994. Pedogeografija. Oddelek za geografijo, Filozofska fakulteta, Univerza v Ljubljani. Ljubljana.

Mark, D.M., 1988. Network models in geomorphology. In: "Modelling in Geomorphological Systems" (urednika, Anderson, M. G., Wiley, J.). Str. 73-97.

Metodika terenskog ispitivanja zemljišta i izrada pedoloških karata. Priručnik za ispitivanje zemljišta, knjiga IV. Beograd 1967.

Moore, I.D., Gessler, P.E., Nielsen, G.A., Peterson, G.A., 1993. Soil attribute prediction using terrain analysis. Soil Science Society of America Journal 57. Str. 443-452.

O'Callaghan, J.F., Mark, D.M., 1984. The extraction of drainage networks from digital elevation data. Computer Vision, Graphics, and Image Process, 28(3). Str. 323-344.

Ogrin, D., 1996. Podnebni tipi v Sloveniji. Geografski vestnik, letn. 68, str. 39-56. Zveza geografskih društev Slovenije, Ljubljana.

Perko, D., Orožen Adamič, M., 1998. Slovenija: Pokrajine in ljudje. Mladinska knjiga. Ljubljana.

Prus, T., 2000. Klasifikacija tal. Študijsko gradivo za ciklus predavanj 2000. (spletno gradivo: http://www.bf.uni-lj.si/cpvo/Novo/PDFs/KlasifikacijaTal.pdf, citirano: 7.6.2004).

Center za pedologijo in varstvo okolja, Biotehnična fakulteta, Univerza v Ljubljani.

Quinn, P. F., Beven, K. J., Lamb R., 1995. The ln(a/tanb)Index: How to Calculate it and how to use it Within the Topmodel Framework. Hydrological Processes, 9. Str. 161-182.

Radinja, D., 1996. Polhograjsko hribovje. Zahodni predalpski svet. Regionalnogeografska monografija Slovenije (II. Del). Geografski inštitut, ZRCSAZU. Ljubljana. Str 55-69.

Repe, 2004 - Soils of Slovenia. Slovenia - A geographical overview. Zveza geografskih društev Slovenije. Založba ZRC, Ljubljana.

Repe, B., 2001. Terenske in laboratorijske metode proučevanja prsti. Oddelek za geografijo, Filozofska fakulteta, Univerza v Ljubljani. Ljubljana.

Repe, B., 2006. Pedogeografska karta in njena uporabnost v geografiji. Doktorska disertacija. Oddelek za geografijo, Filozofska fakulteta, Ljubljana. 432 str.

Soil Survey Division Staff, 1993. Soil survey manual. Soil Conservation Service. U.S. Department of Agriculture Handbook 18. http://soils.usda.gov/technical/manual/ (citirano: 28.3.2006).

SOTER, 1995. Global And National Soils And Terrain Digital Databases (Procedures Manual). World Soil Resources Reports, 74 Rev. 1. Land and Water Development Division, Food and Agriculture Organization of the United Nations. (http://www.usoils. jrc.it/projects/soter/Soter, citirano: 16.11.2004). str. 137.

Stritar, A., 1991: Pedologija (kompendij). Biotehniška fakulteta, Ljubljana. 122 str.

Tarboton, D. G., 1997. A New Method for the Determination of Flow Directions and Contributing Areas in Grid Digital Elevation Models. Water Resources Research, 33(2). Str. 309-319 (http://www.engineering.usu.edu/dtarb/dinf.pdf; citirano 17.4.2006).

Tarboton, D. G., 2005. Terrain Analysis Using Digital Elevation Models (TauDEM). Priročnik za uporabo programskega paketa TAUDEM (http://hydrology.neng.usu.edu/taudem/; citirano, 11.4.2006)

Vovk Korže, A., Lovrenčak F., 2001. Priročnik za laboratorijske analize prsti v geografiji. Oddelek za geografijo, Filozofska fakulteta, Univerza v Ljubljani in Oddelek za geografijo, Pedagoška fakulteta v Mariboru. Ljubljana, Maribor. 
Vovk Korže, A., Lovrenčak F., 2004. Priročnik za spoznavanje prsti na terenu. Oddelek za geografijo, Filozofska fakulteta, Univerza v Ljubljani. Ljubljana.

Vrščaj, B., 1996. Izdelava modela podatkovnega segmenta talnega informacijskega sistema. Diplomska naloga. Oddelek za agronomijo, Biotehnična fakulteta, Univerza v Ljubljani. Ljubljana. 81 str.

Vrščaj, B., Zupan, M., 2001. Vaje iz pedologije II. del - Uporaba pedoloških podatkov (spletno gradivo:http://www.bf.uni-lj.si/cpvo/Novo/PDFs/VajePedologija2.pdf, citirano: 7.6.2004). Center za pedologijo in varstvo okolja, Biotehnična fakulteta, Univerza v Ljubljani.

Western, A.W., Grayson, R.B., Bloschl, G., Willgoose, G.R., McMahon, T.A., 1999. Observed spatial organization of soil moisture and its relation to terrain indices. Water Resources Research 35(3). American Geophysical Union. Str. 797-810.

\section{SOIL WATER CONTENT AND ITS DISTRIBUTION ACCORDING TO RELIEF}

\section{Summary}

Water is a very important factor of soil formation. It represents also a very significant factor in Slovene soil classification (on the first level soils are divided on the of type water influence). Nevertheless soil water and its distribution is usually not studied independently but as an integral part of other factors, especially relief and climate.

Soil water distribution determination requires a lot of field research. Field ascertainments and later laboratory measurements give point oriented data about absolute or relative soil water content which is relatively difficult to generalize on entire area of study.

For soil water distribution a topographic wetness index (TWI) had been used. Topographic wetness index shows a degree of water accumulation in a given location and is a function of slope and specific catchment area upslope of this point. Topographic wetness index calculation methodology depends on the way specific catchment area is determined. In fact calculation of the specific catchment area is defined by theoretical down slope water flow from selected to surrounding neighboring cells. Procedures are numerous but in general they could be divided in single and multiple flow algorithms.

Topographic wetness index is calculated from digital elevation model. In our case it was

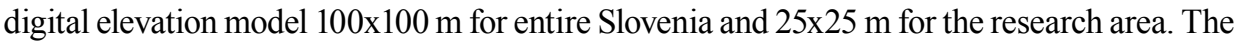
calculation included several steps. The first was the filling of pits in the relief and next the calculation of several surfaces followed: direction of water flow, water flow accumulation, specific catchment area for every cell, inclination and finally topographic wetness index.

Typical values of topographic wetness index range from to 2 to 30 . Lower values, below 10 represent upper and steeper parts of slopes and watersheds where runoff is expected. Here drier conditions, erosion of soil material occur and therefore shallower soils are common. Higher values, above 20 represent lower and gentler parts of slopes and watersheds, where water accumulation is expected. These are lowland and flat areas, close to local erosion base or water streams. They are characterized by waterlogging, soil material accumulation 
therefore soil cover is thicker and hydromorphic conditions are common (gleying and pseudogleying).

Topographic wetness index forecasts a theoretical water accumulation over surface, with exclusion of the vegetation cover. In normal conditions water infiltrates into soil cover and seeps slowly, but generally still in the same direction and proportionally as predicted. Index does not to take into consideration the loss of water due to evaporation, transpiration, leaking into permeable parent material or heavy soil texture retention etc. Correct estimation of soil water distribution can therefore only be made by knowing geolithological, climatic, vegetal and pedological characteristics.

Distribution of soil water through topographic wetness index had been closely studied in Polhograjsko hills, where the following conclusions were drawn:

- The lowest values (under 5) occurred far from local erosion base of the research area. At the same time they represent the areas with the highest absolute and relative elevationpeaks and ridges of the hills in the research area.

- Hilly characteristics of the research area result in domination of middle range lower $(5-10)$ and higher $(10-15)$ values. Former include leveled and convex slopes, all very steep slopes, small plains high above lowland, while later include lower parts of the slopes, near ravines.

- High values (15-18) lie in concave parts of slopes, on the bottom of ravines, far from local erosion base and on passages from slopes to lowland, where foothill colluvium in accumulating.

- The highest values (above 18) are spread across entire flat lowland and on the bottom of all major river valleys where all the water is accumulated before it leaves the research area. Highest values also occur next to the streams irrespective of size and distance from erosion base.

As expected the highest topographic index can be found within areas of gleysols, followed by fluvisols. This is not surprising because water represents the man factor of soil formation for those two soil types. Also luvisols possess higher values of TWI. Their position is on relatively flat relief where water is accumulated and can percolate only downward through profile causing eluviation. Using topographic wetness index we can easily distinguish between dystric leptosols and dystric cambisols. Dystric leptosols lie on upper parts of slopes, with inclination higher than $25^{\circ}$ and TWI value lower then 10. Less distinctive are the differences between rendzic leptosols and chromic cambisols. Although we could not separate these two types on slope differences, TWI enables better differentiation. Rendzic leptosols form in drier parts where water shows less influence and the runoff in quite high, but these conditions do not necessary occur only on steepest slopes. 